\title{
Methylation of SERPINA1 gene promoter may predict chronic obstructive pulmonary disease in patients affected by acute coronary syndrome
}

\author{
John Charles Rotondo 1 [0], Giorgio Aquila', Lucia Oton-Gonzalez' , Rita Selvatici', Paola Rizzo 2,4, \\ Monica De Mattei ${ }^{1}$, Rita Pavasini ${ }^{3}$, Mauro Tognon ${ }^{1} \mathbb{B}$, Gianluca Calogero Campo ${ }^{3^{*}+}$ and Fernanda Martini $i^{1,4^{*}+}$
}

\begin{abstract}
Background: Diagnostic biomarkers for detecting chronic obstructive pulmonary disease (COPD) in acute coronary syndrome (ACS) patients are not available. SERPINA1, coding for the most potent circulating anti-inflammatory protein in the lung, has been found to be differentially methylated in blood cells from COPD patients. This study aimed to investigate the methylation profile of SERPINA1 in blood cells from ACS patients, with (COPD+) or without COPD (COPD-).

Methods: Blood samples were from 115 ACS patients, including 30 COPD+ and 85 COPD- according to lung function phenotype, obtained with spirometry. DNA treated with sodium bisulfite was PCR-amplified at SERPINA1 promoter region. Methylation analysis was carried out by sequencing the PCR products. Lymphocytes count in ACS patients was recorded at hospital admission and discharge.

Results: SERPINA1 was hypermethylated in 24/30 (80\%) COPD+ and 48/85 (56.5\%) COPD - $(p<0.05)$. Interestingly, at hospital discharge, lymphocytes count was higher in COPD - patients carrying SERPINA1 hypermethylated $\left(1.98 \times 10^{3} \pm 0.6 \mathrm{cell} / \mu \mathrm{l}\right)$ than in COPD - carrying SERPINA1 hypomethylated $\left(1.7 \times 10^{3} \pm 0.48 \mathrm{cell} / \mathrm{\mu l}\right)(p<0.05)$.

Conclusions: SERPINA1 is hypermethylated in blood cells from COPD+ patients. COPD - carrying SERPINA1 hypermethylated and high lymphocytes count may be at risk of COPD development. Therefore, SERPINA1 hypermethylation may represent a potential biomarker for predicting COPD development in ACS patients.
\end{abstract}

Keywords: Chronic obstructive pulmonary disease, Acute coronary syndrome, COPD, ACS, SERPINA1, Alpha 1-antitrypsin

\section{Introduction}

Chronic obstructive pulmonary disease (COPD) is a chronic inflammatory lung disease that causes obstructed

\footnotetext{
*Correspondence: cmpglc@unife.it; mrf@unife.it

†Gianluca Calogero Campo and Fernanda Martini contributed equally ${ }^{1}$ Department of Medical Sciences, University of Ferrara, Ferrara, Italy

${ }^{3}$ Cardiology Unit, Azienda Ospedaliera Universitaria Di Ferrara, Ferrara, Italy

Full list of author information is available at the end of the article
}

airflow from the lungs [1]. It is caused by long-term exposure to particulate matter, most often from cigarette smoke [1]. Acute coronary syndrome (ACS) results from acute obstruction of a coronary artery [2]. Several studies suggest that ACS patients with concomitant COPD have a poor prognosis [3-5]. However, COPD is frequently undiagnosed in ACS patients, with a significant delay in the treatment and a negative impact on short- and original author(s) and the source, provide a link to the Creative Commons licence, and indicate if changes were made. The images or other third party material in this article are included in the article's Creative Commons licence, unless indicated otherwise in a credit line to the material. If material is not included in the article's Creative Commons licence and your intended use is not permitted by statutory regulation or exceeds the permitted use, you will need to obtain permission directly from the copyright holder. To view a copy of this licence, visit http://creativecommons.org/licenses/by/4.0/. The Creative Commons Public Domain Dedication waiver (http://creativeco mmons.org/publicdomain/zero/1.0/) applies to the data made available in this article, unless otherwise stated in a credit line to the data. 
long-term prognosis [5]. The gold standard for COPD diagnosis is the spirometry.

SERPINA1 gene encodes for Alpha-1 antitrypsin (AAT), a blood protease of $52 \mathrm{kDa}$ constitutively released from the hepatocytes [6]. AAT is involved in inflammatory processes $[7,8]$. Indeed, this protein plays a protective role on the healthy cells adjacent to the inflamed tissue where it inhibits different proteases, including the elastase produced by neutrophils [7]. The activity of AAT is very high in the lower respiratory tract where it provides more than $90 \%$ of the defenses against the elastolytic load of neutrophils $[9,10]$. The relevance of AAT in COPD is evident in individuals carrying mutations in SERPINA1 gene where absence or alteration of the protein in association with cigarette consumption predisposes to the risk of developing COPD [11].

SERPINA1 gene is $12.2 \mathrm{~kb}$ and maps on chromosome 14q32.1 [12]. It consists of 7 exons called IA, IB, IC and II-III-IV-V, and six introns [13]. Transcriptional regulation occurs in exons IA, IB and IC, in a tissue-specific manner [13]. IA and IB regulate transcription in the monocytes and macrophages and IC in hepatocytes [14, 15]. SERPINA1 is also an inducible gene upon activating its inflammation-responsive promoter in hepatocytes, monocytes and macrophages [7, 16, 17]. High levels of circulating AAT, fourfold to sixfold higher than baseline levels, are present during the course of inflammation, infections and late pregnancy [18-21].

In a recent study we have performed a comprehensive assessment of SERPINA1 gene promoter methylation profile in peripheral blood mononuclear cells (PBMCs) from healthy subjects [21]. We showed that SERPINA1 gene promoter is hypermethylated in healthy individuals, such as blood donors, but hypomethylated in pregnant women at the third trimester of pregnancy. These findings suggest that SERPINA1 gene is normally silenced in blood cells of healthy individuals, but it is induced under emergency conditions, such as late pregnancy, when women are highly exposed to the risk of inflammations and infections [21].

Based on our recent findings, in this study we aimed to verify whether methylation of SERPINA1 gene promoter may differ between ACS patients with COPD (COPD+) and without COPD (COPD-). To this aim, the methylation profile of SERPINA1 gene promoter was investigated in blood cells from COPD+ and COPD- patients.

\section{Methods}

\section{Sample population}

Blood samples were collected from 115 ACS patients (mean age \pm standard deviation $[S D], 65 \pm 9$ yrs) at the University Hospital of Ferrara, Ferrara, Italy. The inclusion criteria comprised smokers or former smokers $(\geq 10$ pack/years) patients hospitalized with a clinical diagnosis of ACS, as defined by current European guidelines [22]. Exclusion criteria included previous diagnosis of COPD and/or asthma, known pulmonary diseases other than COPD, ongoing pneumonia, ongoing heart failure, documented or suspicion of malignant disease, life expectancy $<1$ year, recent thoracic trauma.

\section{Definition of undiagnosed COPD}

Clinical and laboratory data as well as blood samples were collected for all patients during hospitalization. Two months after discharge, all patients underwent spirometry to verify the presence of COPD. A spirometry was performed by two expert pulmonologists and revised by an independent reviewer blinded to patients' clinical conditions and outcomes. Spirometry was performed according to standardized procedures [23]. Briefly, COPD was diagnosed in the presence of: (1) exposure to risk factors for the disease (all patients enrolled in the study were current or former smokers); (2) presence of chronic respiratory symptoms (mainly shortness of breath, cough and sputum) and (3) post-bronchodilator fixed ratio forced expiratory volume at first second (FEV1)/forced vital capacity $(\mathrm{FVC})<0.7$.

\section{Blood collection and leukocyte count}

A venous blood sample was collected from all ACS patients at the time of both admission and hospital discharge. Leukocyte count was performed by flow cytometry with the automated cell counter Sysmex XN. When needed, a blood smear was prepared for microscopic evaluation and accurate quantification of total lymphocytes count.

\section{DNA extraction and DNA PCR suitability}

DNA was isolated from total blood using QIAamp DNA Blood Mini Kit (Qiagen, Milan, Italy), as described [24]. After purification, DNA was quantified by spectrophotometric reading (NanoDrop 2000, Thermo Scientific) [21] and then evaluated for its PCR suitability by amplification for $\beta$-globin gene sequence [25].

\section{Treatment of DNAs with sodium bisulfite and SERPINA1 PCR}

Methylation analysis was carried out by DNA treatment with sodium bisulfite, using the Epitect Bisulfite kit (Qiagen, Milan, Italy), as reported [21]. Treated DNA was purified with DNA purification columns (Epitect Bisulfite kit, Qiagen, Milan, Italy) and then subjected to PCR amplification for SERPINA1 gene promoter (GenBank accession number: NG_008290.1). Briefly, 150 ng of DNA was amplified using the primers forward $5^{\prime}$-TTTTGG TTTAGTTTAGGATTTTGAGG- ${ }^{\prime}$ and reverse $5^{\prime}$-ACC 
TACCAATTATTAATACCAAATCTATAC-3' $[21,26]$. These primers amplify a promoter region of $375 \mathrm{bp}$ (GenBank accession number: NG_008290.1, position 47115085), which contains $8 \mathrm{CpG}$ dinucleotides. Among these CpGs, CpG number 1 (CpG-1) and CpG-8 have been previously found hypomethylated in association with lower average lung function phenotypes and COPD [26], while CpG- 6 belongs to a CCGCCC-box regulatory consensus sequence of the promoter region (Fig. 1a) [21]. PCR program was: $10 \mathrm{~min}$ of denaturation at $95^{\circ} \mathrm{C}$ followed by 40 cycles of $1 \mathrm{~min}$ at $95{ }^{\circ} \mathrm{C}, 1 \mathrm{~min}$ at $65^{\circ} \mathrm{C}$ and 2 min at $72{ }^{\circ} \mathrm{C}$ and a final extension for 5 min at $72{ }^{\circ} \mathrm{C}$ [21]. A PCR-negative control containing distilled water without DNA, was included per reaction. PCR products were run onto $2 \%$ agarose gel electrophoresis and stained with ethidium bromide.

\section{DNA sequencing of SERPINA1 PCR products}

To evaluate the methylation levels of SERPINA1 promoter, PCR products were sequenced by direct sequencing [27]. Briefly, PCR products were purified using the QIAquick PCR Purification Kit (Qiagen, Milan, Italy) and then subjected to direct sequencing using the automated ABI-Prism-3130X DNA sequencer (Applied Biosystems, Monza, Italy) [25], as performed before [28]. SERPINA1 sequences showing more than or equal to 5 out of 8 methylated CpGs $(\geq 50 \%)$ were considered hypermethylated $[27,29]$.

\section{Statistical analysis}

Continuous data were tested for normal distribution with the Kolmogorov-Smirnov test. Normally distributed values were presented as mean $\pm \mathrm{SD}$ and compared by $t$ test [30]. Otherwise, median [interquartile range] and Mann-Whitney $U$ were used. The Chi-square trend

\section{a}

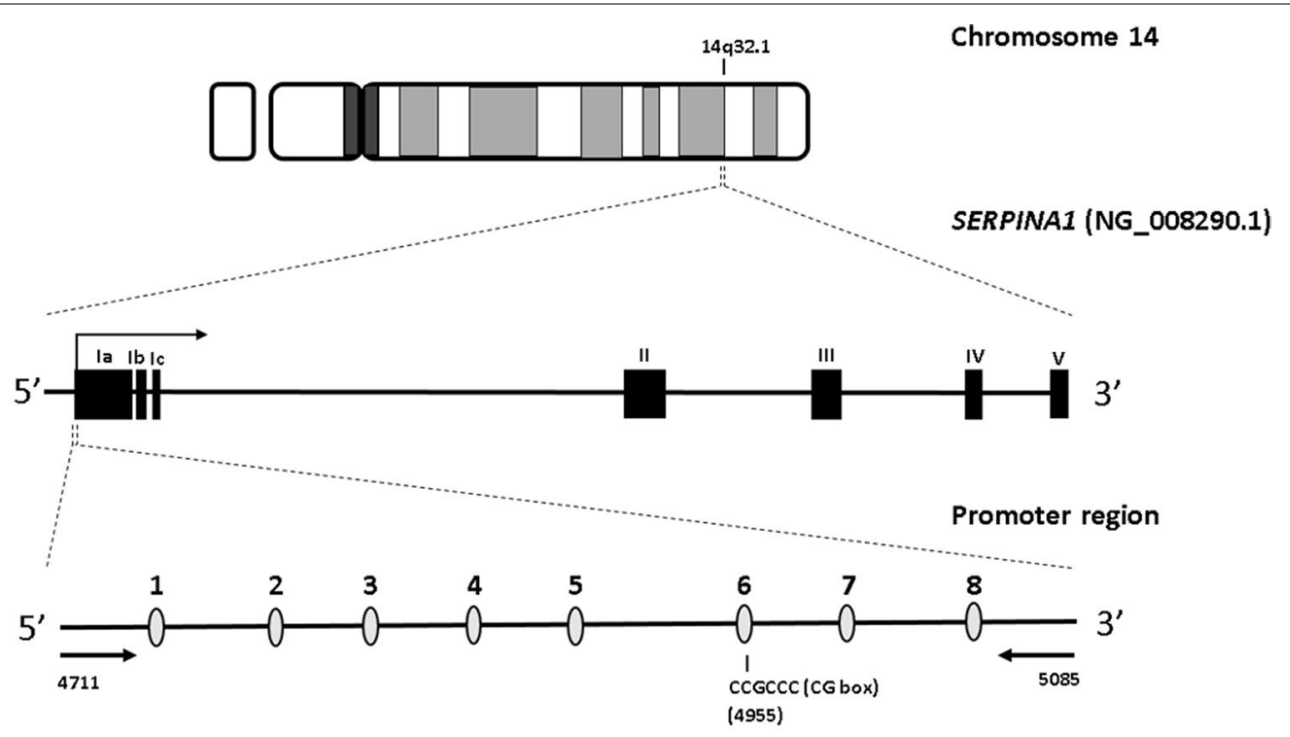

b

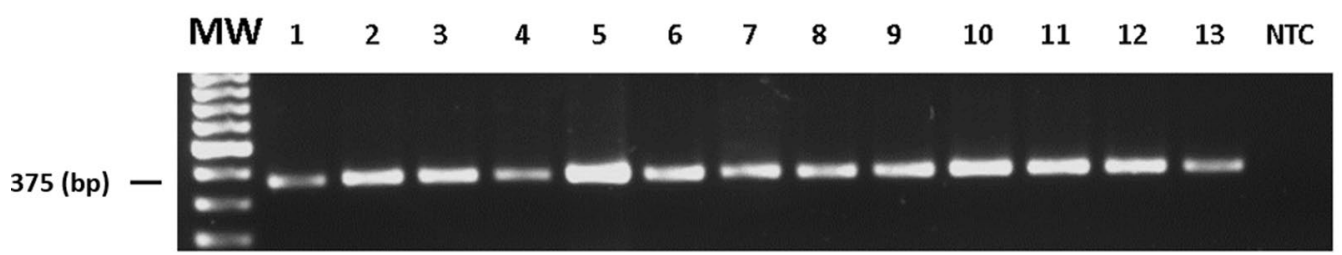

Fig. 1 a Genomic structure of chromosome 14, SERPINA1 gene and SERPINA1 promoter region. Upper line: graphical representation of chromosome 14. SERPINA1 gene is located on the long arm of the chromosome at 14q32.1. Middle line: graphical representation of SERPINA1 gene (GenBank accession number NG_008290.1). The gene includes seven exons (la-lc, II, III, IV and V) and six introns. Filled-in boxes and horizontal arrow indicate gene exons and orientation, respectively. Bottom line: analyzed SERPINA1 promoter sequence with 8 CpGs including the 6th CpG of the amplified region located at the CG-box consensus sequence. The horizontal arrows represent the primers. $\mathbf{b}$ Bisulfite PCR of SERPINA1 promoter region. MW, molecular weight; NTC, no template control. Columns 1-13, representative bisulfite-treated DNAs from acute coronary syndrome (ACS) patients with chronic obstructive pulmonary disease (COPD+, columns 1-6) and without COPD (COPD-, columns 7-13) 
test with Yate's correction [31] was used to compare the observed SERPINA1 epigenotypes, i.e., DNA hypermethylation and hypomethylation, among COPD+ and COPD - groups. Lymphocyte values were analyzed with D'Agostino-Pearson test for normality, and groups were compared employing the nonparametric Mann-Whitney $U$ test $[32,33]$. Spearman correlation analysis was applied to evaluate age-related variations in SERPINA1 promoter methylation by matching the level of methylation to the age of each individual [30]. Multiple linear regression model has been used to estimate the associations between SERPINA1 epigenotypes and lymphocytes count. Statistical analyses were carried out employing the $\mathrm{R}$ software package (version 3.5.0) and using the GraphPad Prism for Windows (version 5.0, GraphPad) [34]. $p$ values less than $0.05(p<0.05)$ were considered statistically significant [35].

\section{Results}

\section{ACS patients}

Population characteristic of ACS patients stratified according to the presence of COPD are reported in Table 1. Overall, 115 patients were included in the analysis. Of those, after spirometry, 30 (26\%) were confirmed with COPD. Of note, only age, respiratory health screening questionnaire (RSHQ), $\mathrm{FEV}_{1}$ and pack-year resulted to be significantly different between COPD- $(n=85)$ and $\mathrm{COPD}+(n=30)$ : age $63 \pm 9$ versus $70 \pm 8$ years, $p=0.001 ; \mathrm{RSHQ}>1929 \%$ versus $57 \%, p=0.008 ; \mathrm{FEV}_{1}$ (mean $L \pm \mathrm{SD}$ ) $2.9 \pm 0.7$ versus $2.0 \pm 0.5, p<0.001$; packyear, mean \pm SD $34 \pm 23$ vs $45 \pm 38, p<0.05$ in COPDvs. COPD+, respectively.

\section{SERPINA1 gene promoter methylation analysis}

In order to profile the methylation status, SERPINA1 was PCR amplified in a promoter region containing 8 CPG dinucleotides (Fig. 1a). PCR amplifications were efficiently obtained in all blood samples from all patients (Fig. 1b).

The prevalence of methylation in SERPINA1 gene promoter was evaluated by sequencing analysis of PCR products. SERPINA1 gene promoter was found to be hypermethylated in 72/115 (62.6\%) of ACS patients. SERPINA1 was found to be hypermethylated in $24 / 30$ (80\%) COPD+ and in 48/85 (56.5\%) COPD- (Fig. 2a, b). The difference in SERPINA1 hypermethylation between COPD + and COPD - ACS patients resulted statistically significant $(p<0.05$; Fig. $2 c)$.

As CpG-6 dinucleotide has been recently associated with the epigenetic regulation of SERPINA1 gene by promoter methylation in blood cells from healthy individuals [21], we specifically investigated the methylation status of CpG-6 in SERPINA1 hypermethylated and
Table 1 Population characteristics according to the presence of undiagnosed chronic obstructive pulmonary disease (COPD)

\begin{tabular}{|c|c|c|c|}
\hline General characteristics, mean \pm SD & $\begin{array}{l}\text { COPD- } \\
(n=85)\end{array}$ & $\begin{array}{l}\text { COPD+ } \\
(n=30)\end{array}$ & $p$ value \\
\hline Age, years & $63 \pm 9$ & $70 \pm 8$ & 0.001 \\
\hline $\mathrm{BMI}, \mathrm{Kg} / \mathrm{m}^{2}$ & $27.7 \pm 4.2$ & $27 \pm 3.6$ & 0.420 \\
\hline Male, $n^{\circ}(\%)$ & $73(86)$ & $23(77)$ & 0.243 \\
\hline \multicolumn{4}{|l|}{ CV risk factors and comorbidities, $n^{\circ}(\%)$} \\
\hline Diabetes & $19(22)$ & $9(30)$ & 0.401 \\
\hline Hypertension & $58(68)$ & $18(60)$ & 0.413 \\
\hline Family history of CAD & $23(27)$ & $8(27)$ & 0.967 \\
\hline Dyslipidemia & $47(55)$ & $13(43)$ & 0.260 \\
\hline Pre-Ml & $10(12)$ & $8(27)$ & 0.053 \\
\hline Pre-PCl & $17(20)$ & $3(10)$ & 0.214 \\
\hline Pre-CABG & $3(4)$ & $2(7)$ & 0.469 \\
\hline $\mathrm{AF}$ & $8(9)$ & $3(10)$ & 0.925 \\
\hline PAD & $4(5)$ & $2(7)$ & 0.678 \\
\hline \multicolumn{4}{|l|}{ COPD parameters } \\
\hline $\mathrm{RHSQ}>19, \mathrm{n}^{\circ}(\%)$ & $25(29)$ & $17(57)$ & 0.008 \\
\hline FEV1, L, mean $\pm S D$ & $2.9 \pm 0.7$ & $2.0 \pm 0.5$ & $<0.001$ \\
\hline Smoker, $n^{\circ}(\%)$ & $39(46)$ & $15(50)$ & 0.698 \\
\hline Former smokers, $n^{\circ}(\%)$ & $46(54)$ & $15(50)$ & 0.698 \\
\hline Pack years, mean $\pm S D$ & $34 \pm 23$ & $45 \pm 38$ & 0.049 \\
\hline \multicolumn{4}{|c|}{ Clinical presentation and coronary vessel disease, $n^{\circ}(\%)$} \\
\hline STEMI & $38(45)$ & $15(50)$ & 0.617 \\
\hline NSTEMI & $27(32)$ & $10(33)$ & 0.874 \\
\hline Unstable angina & $20(24)$ & $5(17)$ & 0.433 \\
\hline Descending artery & $67(79)$ & $18(60)$ & 0.051 \\
\hline Circumflex artery & $44(52)$ & $12(40)$ & 0.268 \\
\hline Right coronary artery & $61(72)$ & $18(60)$ & 0.232 \\
\hline Left main & $12(14)$ & $5(17)$ & 0.551 \\
\hline \multicolumn{4}{|l|}{ Therapy, $n^{\circ}(\%)$} \\
\hline Aspirin & $84(99)$ & $30(100)$ & 0.553 \\
\hline P2Y12 inhibitor & $85(100)$ & $30(100)$ & 0.999 \\
\hline Beta-blockers & $72(85)$ & 28(93) & 0.228 \\
\hline ACE inhibitors & $77(91)$ & 28(93) & 0.646 \\
\hline Statins & $83(98)$ & 28(93) & 0.268 \\
\hline \multicolumn{4}{|l|}{ Laboratory data, mean $\pm S D$} \\
\hline Troponin T, ng/dl & $1.99 \pm 2.7$ & $2.3 \pm 4.3$ & 0.643 \\
\hline CK-MB peak & $78 \pm 119$ & $90 \pm 141$ & 0.676 \\
\hline WBC admission, $\mathrm{u} / \mu \mathrm{l}$ & $9.4 \pm 3.05$ & $9.5 \pm 2.94$ & 0.998 \\
\hline WBC discharge, $u / \mu l$ & $8.48 \pm 2.21$ & $7.91 \pm 1.88$ & 0.209 \\
\hline Lymphocytes, $u / \mu l$, admission & $2.14 \pm 0.99$ & $1.95 \pm 0.96$ & 0.365 \\
\hline Lymphocytes, u/ul, discharge & $1.85 \pm 0.57$ & $1.74 \pm 0.73$ & 0.352 \\
\hline Neutrophils, $u / \mu l$, admission & $6.11 \pm 2.66$ & $5.95 \pm 2.06$ & 0.763 \\
\hline 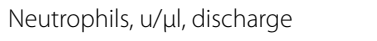 & $5.56 \pm 1.84$ & $4.91 \pm 1.36$ & 0.081 \\
\hline NLR, admission & $3.47 \pm 2.17$ & $3.78 \pm 2.51$ & 0.516 \\
\hline NLR, discharge & $3.24 \pm 1.44$ & $3.39 \pm 1.88$ & 0.639 \\
\hline
\end{tabular}

COPD+: ACS patients, with chronic obstructive pulmonary disease (COPD). COPD-: ACS patients without COPD. WBC: white blood cell, SD: standard deviation, ACE: angiotensin-converting enzyme, STEMI: ST-elevation myocardial infarction, NSTEMI: non-ST-elevation myocardial infarction, MI: myocardial infarction, $\mathrm{PCl}$ : percutaneous coronary intervention, CABG: coronary artery bypass graft, AF: atrial fibrillation, PAD: peripheral artery disease, COPD: chronic 
Table 1 (continued)

obstructive pulmonary disease, FEV1: forced expiratory volume at first second, FVC: forced vital capacity, RHSQ: respiratory health screening questionnaire, HDL: high-density lipoprotein, CAD: coronary artery disease, CV: cardiovascular,

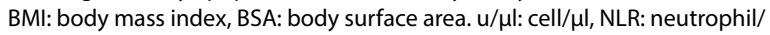
lymphocyte ratio

SERPINA1 hypomethylated samples. To this aim, ACS patients were first stratified on the basis of the degree of methylation of SERPINA1: 5 to 8 (hypermethylated) and 1 to 4 (hypomethylated). Then, the number of CpG-6 status of these CpG sites in association with COPD. CpG-1 was found methylated in 24/30 (80\%) and 60/85 (70.6\%) of COPD+ and COPD - , respectively $(p>0.05)$. Furthermore, CpG-8 resulted methylated in 11/30 (36\%) of COPD + and in 34/85 (40\%) of COPD- $(p>0.05)$. These results indicated a lack of association between CpG-1 and/or CpG-8 methylation and COPD.

Moreover, as the mean age was significantly higher in $\mathrm{COPD}+(n=30$, mean age $\pm \mathrm{SD}: 70 \pm 7$ years old $)$ than in COPD $-(n=85$, mean age \pm SD: $63 \pm 9$ years old $)$

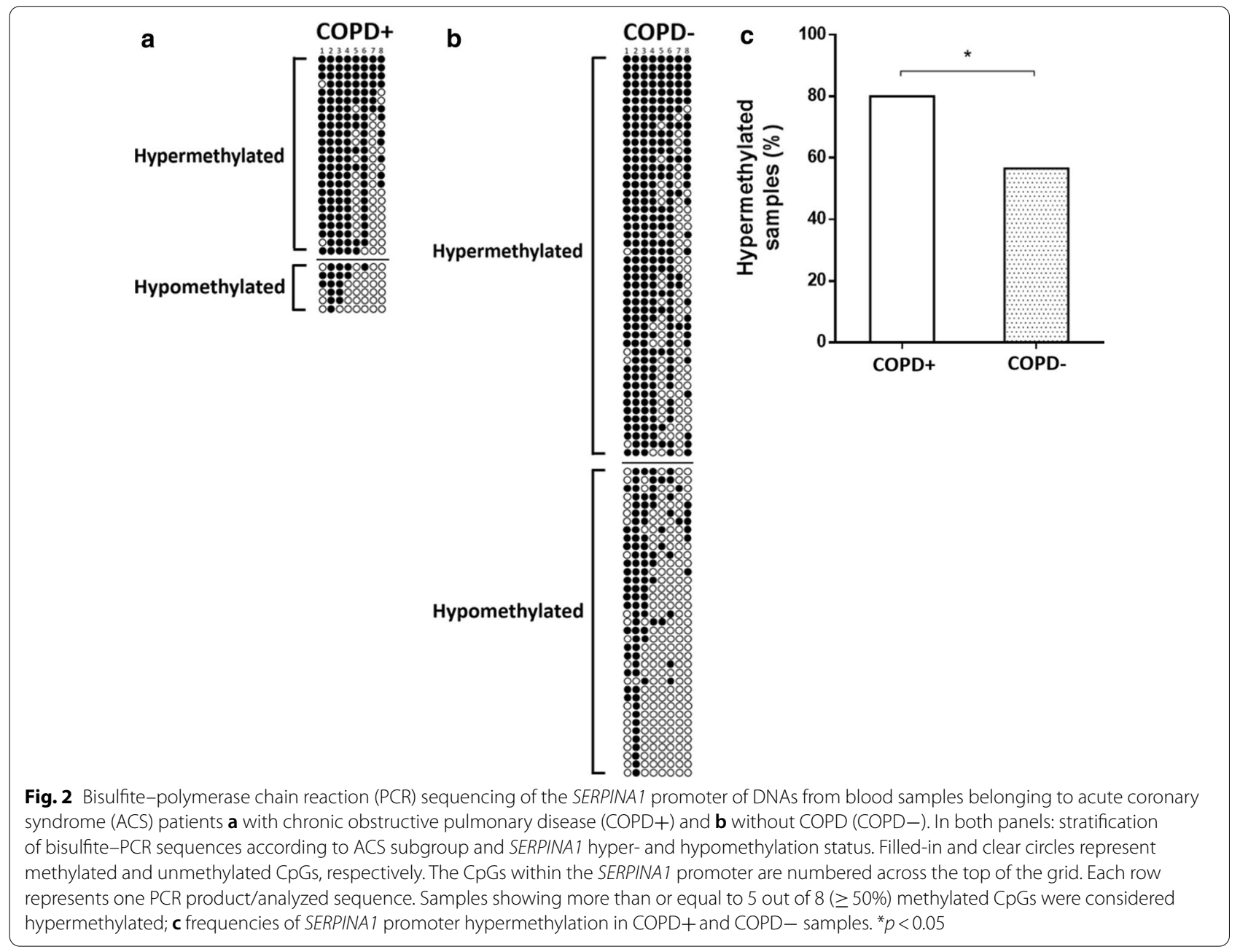

methylated and CpG-6 un-methylated was counted in the two groups (Fig. 3a). CpG-6 was found to be methylated in 68/72 (94.4\%) hypermethylated ACS samples and in $9 / 43$ (20.9\%) hypomethylated ACS samples $(p<0.0001$; Fig. 3b).

Since hypomethylated CpG-1 and CpG-8 sites have been associated with lower average lung function phenotypes and COPD [26], we investigated the methylation $(p<0.001)$, age-related changes in SERPINA1 promoter methylation of ACS patients were assessed. Results indicate a lack of correlation between age and SERPINA1 promoter methylation in ACS patients $(r=-0.071$ and $p>0.05)$ as well as between age and SERPINA1 methylation in both COPD $+(r=-0.073, p>0.05)$ and COPDgroups $(r=-0.166, p>0.05)$. These results indicate that SERPINA1 promoter methylation is age independent 
(See figure on next page.)

Fig. 3 a Acute coronary syndrome (ACS) patient's stratification according to the number of CpGs methylated in SERPINA1, i.e., hypermethylation and hypomethylation. Methylated and unmethylated CpG-6 in SERPINA1 hypermethylated and hypomethylated samples, respectively, are reported. Samples showing more than or equal to 5 out of $8(\geq 50 \%)$ methylated CpG dinucleotides were considered hypermethylated. Filled-in and clear circles represent methylated and unmethylated $\mathrm{CpGs}$, respectively. The CpGs within the SERPINA1 promoter are numbered across the top of the grid. Each row represents one PCR product/analyzed sequence. Vertical red box highlights CpG-6 dinucleotides across hypermethylated and hypomethylated samples. b Frequencies of methylated CpG-6 in SERPINA1 promoter hypermethylated and hypomethylated ACS samples. ${ }^{* * * *} p<0.0001$

in ACS patients with and without COPD. Thus, age did not represent a possible cofounder factor for SERPINA1 methylation analysis, as reported in healthy subjects [21].

In addition, in order to exclude diabetes as a confounding factor, a correlation between diabetes and SERPINA1 promoter methylation was assessed. The whole pool of ACS patients $(n=115)$ was stratified in patients with $(n=28)$ and without $(n=87)$ diabetes, and SERPINA1 hypermethylation rates were compared. A total of $67.9 \%(19 / 28)$ and $60.9 \%$ (53/87) of ACS patients with and without diabetes, respectively, presented SERPINA1 hypermethylation $(p>0.05)$. ACS patients were afterward stratified according to diabetes status in COPD + with $(n=9)$ and without diabetes $(n=21)$ as well as in COPD - with $(n=19)$ and without diabetes $(n=66)$, and SERPINA1 hypermethylation rates were compared. SERPINA 1 was hypermethylated in $100 \%$ (9/9) of COPD + patients with diabetes and in $71.4 \%(15 / 21)$ of COPD + patients without diabetes $(p>0.05)$. Moreover, $52.6 \%(10 / 19)$ and $57.6 \%(38 / 66)$ of COPD - patients with and without diabetes, respectively, presented SERPINA1 hypermethylation $(p>0.05)$. Thus, no differences in SERPINA1 methylation status were observed when analyzing groups according to diabetes. These results indicate that the presence of diabetes did not suppose an excluding factor in our study.

\section{Association of lymphocytes count and SERPINA1 hypermethylation in COPD-}

High levels of circulating lymphocytes are involved in COPD pathogenesis [36-38]. Therefore, lymphocytes count, available from the hospital database, was analyzed in COPD $+(n=30)$ and COPD - $(n=85)$ patients at hospital admission and discharge, by multiple linear regression model. Lymphocytes count was $1.955 \times 10^{3} \pm 0.960$ $\mathrm{cell} / \mu \mathrm{l}$ in COPD + and $2.13 \times 10^{3} \pm 0.98 \mathrm{cell} / \mu \mathrm{l}$ in COPDat hospital admission ( $p>0.05$; Fig. 4a). At hospital discharge, lymphocytes count was $1.73 \times 10^{3} \pm 0.73$ cell/ $\mu \mathrm{l}$ in COPD + and $1.86 \times 10^{3} \pm 0.57 \mathrm{cell} / \mu \mathrm{l}$ in COPD$(p>0.05)$ (Fig. 4b).

Additionally, the relationship between SERPINA1 promoter methylation and lymphocytes count was investigated in admitted/discharged COPD + and COPD - patients. At admission, lymphocytes count was similar in COPD+with SERPINA1 hypermethylation $\left(1.97 \times 10^{3} \pm 0.92 \mathrm{cell} / \mu \mathrm{l}\right)$ and $\mathrm{COPD}+$ with SERPINA1 hypomethylation $\left(1.88 \times 10^{3} \pm 1.05\right.$ cell/ ul) ( $p>0.05$; Fig. $4 c)$, as well as in COPD- with SERPINA1 hypermethylation $\left(2.16 \times 10^{3} \pm 0.95 \mathrm{cell} / \mu \mathrm{l}\right)$ and COPD - with hypomethylation $\left(2.11 \times 10^{3} \pm 1.01 \mathrm{cell} / \mu \mathrm{l}\right)$ $(p>0.05$; Fig. 4c). At discharge, lymphocytes count was similar in COPD+with SERPINA1 hypermethylation $\left(1.81 \times 10^{3} \pm 0.69 \mathrm{cell} / \mu \mathrm{l}\right)$ and COPD + with hypomethylation $\left(1.42 \times 10^{3} \pm 0.73\right)(p>0.05$; Fig. $4 \mathrm{~d})$, whereas it was found to be higher in COPD- with SERPINA1 hypermethylation $\left(1.98 \times 10^{3} \pm 0.6 \mathrm{cell} / \mu \mathrm{l}\right)$ than in COPDwith SERPINA1 hypomethylation $\left(1.7 \times 10^{3} \pm 0.48\right.$ cell/ ul) $(p<0.05$, Fig. 4 d).

Considering that the level of neutrophil count and neutrophil/lymphocyte ratio (NLR) is important prognostic predictors to assess the degree of inflammation [39, 40], these parameters were evaluated in ACS patients with and without COPD at both hospital admission and discharge. Neutrophil count was $5.95 \times 10^{3} \pm 2.06 \mathrm{cell} / \mu \mathrm{l}$ in COPD + and $6.11 \times 10^{3} \pm 2.66 \mathrm{cell} / \mu \mathrm{l}$ in COPD - at hospital admission $(p>0.05)$. At hospital discharge, neutrophil count was $4.91 \times 10^{3} \pm 1.36 \mathrm{cell} / \mu \mathrm{l}$ in COPD + and $5.56 \times 10^{3} \pm 1.84$ cell $/ \mu \mathrm{l}$ in COPD $-(p>0.05)$. NLR resulted to be $3.78 \times 10^{3} \pm 2.51 \mathrm{cell} / \mu \mathrm{l}$ in COPD + and $3.47 \times 10^{3} \pm 2.17 \mathrm{cell} / \mu \mathrm{l}$ in COPD - at hospital admission $(p>0.05)$, and $3.39 \times 10^{3} \pm 1.88 \mathrm{cell} / \mu \mathrm{l}$ in COPD + and $3.24 \times 10^{3} \pm 1.44 \mathrm{cell} / \mu \mathrm{l}$ in COPD- at hospital discharge $(p>0.05)$. Furthermore, no differences in both neutrophil count and NLR were found when comparing hospital admission and discharge values, for both COPD + and COPD - groups $(p>0.05)$. These results indicate that measuring for neutrophil count and/or NLR in ACS patients does not enable to differentiate between COPD + and COPD - ACS patients and cannot help in predicting which ACS patients are at risk of developing COPD.

\section{Discussion}

In the present study, we investigated the methylation status of SERPINA1 gene promoter in blood samples from ACS patients with (COPD+) and without (COPD-) COPD. Our results show that SERPINA1 promoter 
a

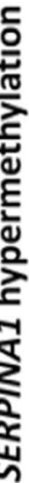

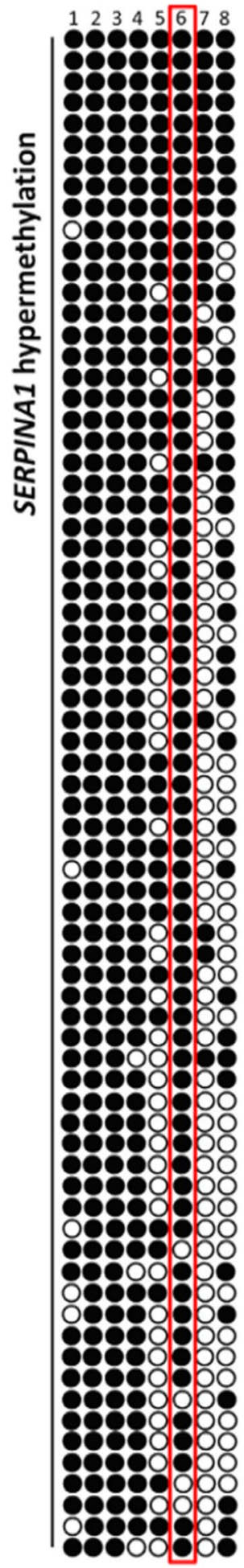

b

Hypermethylated

$\square$ Hypomethylated

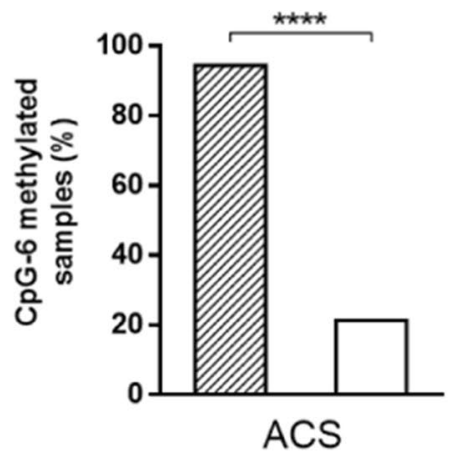



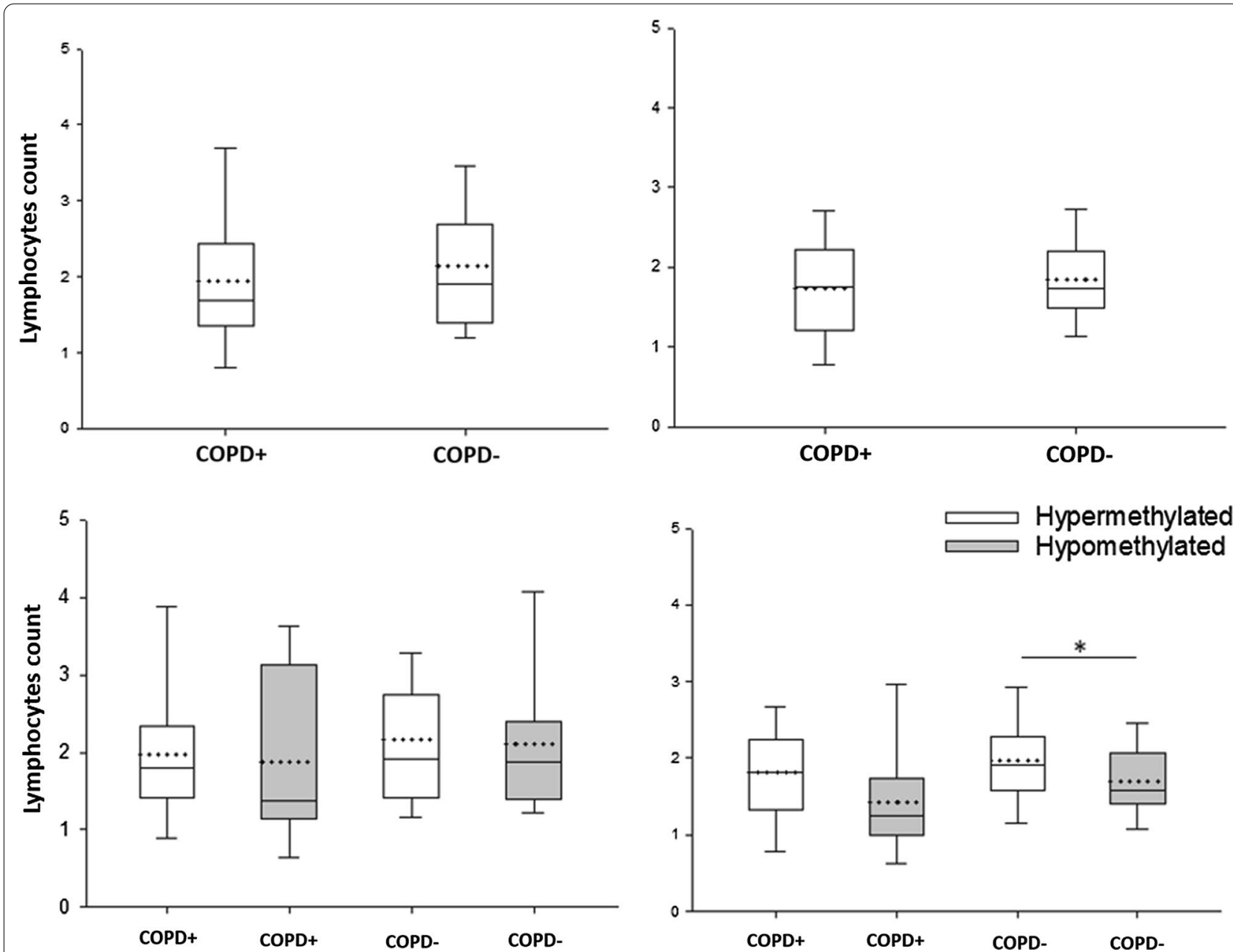

Fig. 4 Boxplot graph resuming the lymphocyte count in acute coronary syndrome (ACS) patients with chronic obstructive pulmonary disease $(\mathrm{COPD}+)$ and without COPD (COPD-) during patient $\mathbf{a}$ admission and $\mathbf{b}$ discharge. Lymphocyte count in COPD + and COPD - patients in $\mathbf{c}$ admission and $\mathbf{d}$ discharge according to SERPINA1 promoter hypermethylated (white) and hypomethylated (grey) statuses. All panels: the lower (Q1) and upper (Q3) quartile, represent observations outside the 5-95 percentile range. The graph also shows the median (continuous middle line) and the mean (dashed line) of lymphocytes $\left(\times 10^{3}\right.$ cell/ $\mu$ l) per study group. ${ }^{*} p<0.05$

methylation is higher in COPD+ patients compared to COPD-. Therefore, SERPINA1 gene promoter hypermethylation may be a potential biomarker for detecting COPD in ACS patients.

SERPINA1 is constitutively expressed in hepatic cells [6]. SERPINA1 is also expressed in inducible manner in hepatocytes and blood cells during the course of the inflammation, infections and late pregnancy $[16,17,19-$ 21]. In PBMCs of healthy individuals the SERPINA1 promoter is hypermethylated except in women in advanced stage of pregnancy, suggesting the gene silencing under normal physiological conditions and the gene expression induction when circulating AAT is needed to be increased [19-21]. In this study, SERPINA1 gene promoter was found to be hypermethylated in $62.6 \%$ of ACS patients. The prevalence of SERPINA1 hypermethylation was higher in COPD $+(80 \%)$ than in COPD - $(56.5 \%)$ patients $(p<0.05)$. This result suggests an association between SERPINA1 hypermethylation and COPD+leading to the hypothesis that lack of AAT expression in blood cells may play a role in the development of COPD in ACS patients. The relevance of AAT in COPD is well known in smokers carrying mutations in SERPINA1 gene where protein deficiency synergizes with smoking in exerting strong adverse effects on lung function, causing COPD [11]. As ACS patients enrolled in this study are all smokers, the adverse effects on lung functions may be mediated by altering promoter methylation in SERPINA1. 
In addition, we specifically analyzed methylation status at CpG-6 site. The dinucleotide CpG-6 falls within a CCGCCC box regulatory consensus region of SERPINA1 promoter. The CCGCCC box is located 46 nucleotides upstream of the transcription start site in SERPINA1 promoter, and it is recognized by transcription factors (TFs) to recruit RNA polymerase, thereby inducing transcription [41]. Methylation at CpG-6 could prevent CG-boxTFs interaction, thereby inducing gene transcriptional repression [42]. In our previous study, we have found that methylation status of CpG-6 reflects the methylation status of SERPINA1, being methylated in SERPINA1 hypermethylated samples and unmethylated in SERPINA1 hypomethylated samples [21]. In this study, nearly $95 \%$ of SERPINA1 hypermethylated samples had CpG-6 methylated, and 79\% SERPINA1 hypomethylated samples had CpG-6 unmethylated. These results extend our previous observations and confirm that CpG-6 may play a pivotal role in epigenetic regulation of SERPINA1 in blood cells [21]. Therefore, the methylation status of CpG-6 may represent a useful marker of expression of SERPINA1 in blood cells.

As high levels of circulating lymphocytes play a role in COPD pathogenesis [36-38], lymphocytes count was analyzed in COPD+and COPD- patients at hospital admission and discharge. Lymphocytes levels were similar in COPD+ and COPD- patients, both at hospital admission and discharge. Nevertheless, COPD- patients carrying SERPINA1 hypermethylated had circulating lymphocytes higher than COPD - patients carrying SERPINA1 hypomethylated, at hospital discharge $(p<0.05)$. This result suggests that COPD- patients carrying SERPINA1 hypermethylated may counteract inflammation less efficiently than COPD - patients carrying SERPINA1 hypomethylated. Therefore, we hypothesize that SERPINA1 hypermethylation may represent a risk factor for developing COPD in ACS patients at risk (smokers) with high levels of circulating lymphocytes in the presence of pharmacological treatments following percutaneous coronary intervention. In this view, ACS patients at risk of developing COPD might be identified by combining epigenetic and hematologic parameters. Follow-up studies should be carried out to verify whether hypermethylated SERPINA1 and lymphocyte count may be useful markers to predict the development of COPD in COPD- patients.

Few studies have explored SERPINA1 methylation in COPD pathogenesis. Our findings are partially in line with a recent meta-analysis study of tobacco-smoke exposed children and adult smokers, which reported association between methylated CpGs located about $32 \mathrm{~kb}$ downstream of SERPINA1 gene and decline in lung functions $[26,43]$. Our data are discordant compared to a previous family-based study of smoking subjects with and without a history of COPD, which found two hypomethylated CpG sites, the CpG-1 and CpG-8 of this study, associated with lower average lung function phenotypes and COPD [26]. It should be pointed out that comparisons between our data and those reported above are difficult to be made, as both patient enrolment criteria and methodological approaches used herein are different. Indeed, we enrolled ACS patients, who were stratified according to the presence/absence of COPD, while previous data were obtained from predominantly smoking adults with/without COPD [26]. About methods, unlike previous investigations that studied epigenome-wide associations, our study was specifically designed to assess the methylation profile of SERPINA1 gene promoter in blood cells from ACS patients.

Our study presents some limitations. First, we studied the epigenetic regulation of SERPINA1 through promoter methylation without validation analyses, such as AAT mRNA and protein expression. However, in our previous study conducted on healthy subjects we determined an association between variations in SERPINA1 promoter methylation in PBMCs and changes in AAT circulating levels [21], while promoter methylation of SERPINA1 in association with gene expression inhibition has been demonstrated in animal models [44-46]. Second, we did not analyze mutations in SERPINA1 gene. Since about 1\% of individuals carry mutations in SERPINA1, it is possible that some COPD+ may be associated with mutations in this gene. Considering that most of the gene mutations occur in the coding region [47], we may infer that SERPINA1 gene regulation by methylation in blood cells is not affected.

In conclusion, the present study shows, for the first time, that SERPINA1 gene promoter is hypermethylated in blood cells from COPD+patients, compared to COPD-. Further, we show that CpG-6 methylation status reflects the methylation status of SERPINA1 promoter. We also found that COPD- patients with $S E R$ PINA1 hypermethylated present higher lymphocytes levels, in the presence of pharmacological treatments following percutaneous coronary intervention, than COPD- patients with SERPINA1 hypomethylated. Collectively, our data indicate that SERPINA1 hypermethylation may play a role in the development of COPD in ACS patients. Therefore, SERPINA1 promoter methylation may be a potential biomarker for detecting/predicting COPD in ACS patients.

\section{Abbreviations}

COPD: Chronic obstructive pulmonary disease; ACS: Acute coronary syndrome; AAT: For alpha1-antitrypsin; CpG-6: CpG number 6; TFs: Transcription factors. 


\section{Acknowledgements}

We thank Professor Georgia Emma Gili for revising the English text of the manuscript.

\section{Authors' contributions}

FM helped in conceptualization; JCR contributed to methodology, visualization and validation; LOG and JCR helped in software and investigation; JCR, RS and GA formally analyzed; RP and GCC helped in resources; JCR, LOG and RP curated the data and statistically analyzed; FM and JCR wrote the original draft; FM, PR and MDM wrote the review and edited; FM and MT supervised the study and acquired the funding; FM and GGC administrated the project. All authors have read and agreed to the published version of the manuscript. All authors read and approved the final manuscript.

\section{Funding}

This study was funded by University of Ferrara, FAR (M.T. and F.M.) and FIR (F.M.) grants; MIUR PRIN 2017 grant (F.M.).

\section{Availability of data and materials}

All data generated or analyzed during this study are included in this published article.

\section{Declarations}

\section{Ethics approval and consent to participate}

The study was conducted in accordance with the Declaration of Helsinki. The protocol was approved by the County Ethical Committee (Authorization number 131295, March 21, 2014)

\section{Consent for publication}

Written informed consent was obtained from all patients.

\section{Competing interests}

The authors declare that they have no competing interests.

\section{Author details}

${ }^{1}$ Department of Medical Sciences, University of Ferrara, Ferrara, Italy. ${ }^{2}$ Department of Translational Medicine and for Romagna, University of Ferrara, Ferrara, Italy. ${ }^{3}$ Cardiology Unit, Azienda Ospedaliera Universitaria Di Ferrara, Ferrara, Italy. ${ }^{4}$ Laboratory for Technologies of Advanced Therapies (LTTA), University of Ferrara, 70 Eliporto Street, 44121 Ferrara, Italy.

Received: 2 January 2021 Accepted: 3 April 2021

Published online: 15 April 2021

\section{References}

1. Decramer M, Janssens W, Miravitlles M. Chronic obstructive pulmonary disease. Lancet Lond Engl. 2012;379:1341-51.

2. Sanchis-Gomar F, Perez-Quilis C, Leischik R, Lucia A. Epidemiology of coronary heart disease and acute coronary syndrome. Ann Transl Med. 2016:4:256

3. Campo G, Pavasini R, Barbetta C, Maietti E, Mascetti S, Biscaglia S, et al. Predischarge screening for chronic obstructive pulmonary disease in patients with acute coronary syndrome and smoking history. Int J Cardiol. 2016:222:806-12.

4. Rothnie KJ, Smeeth L, Pearce N, Herrett E, Timmis A, Hemingway $H$, et al. Predicting mortality after acute coronary syndromes in people with chronic obstructive pulmonary disease. Heart Br Card Soc. 2016:102:1442-8.

5. Mooe T, Stenfors N. The Prevalence of COPD in individuals with acute coronary syndrome: a Spirometry-Based Screening Study. COPD. 2015;12:453-61.

6. Torres-Durán M, Lopez-Campos JL, Barrecheguren M, Miravitlles M, Martinez-Delgado B, Castillo S, et al. Alpha-1 antitrypsin deficiency: outstanding questions and future directions. Orphanet J Rare Dis. 2018;13:114.
7. Yuan Y, DiCiaccio B, Li Y, Elshikha AS, Titov D, Brenner B, et al. Anti-inflammaging effects of human alpha-1 antitrypsin. Aging Cell. 2018;17:e12694. https://doi.org/10.1111/acel.12694.

8. Martini F, De Mattei M, Contini C, Tognon MG. Potential use of alpha-1 anti-trypsin in the Covid-19 treatment. Front Cell Dev Biol [Internet]. 2020 [cited 2020 Dec 24];8. Available from: https://doi.org/10.3389/fcell.2020. 577528/full

9. Dunlea DM, Fee LT, McEnery T, McElvaney NG, Reeves EP. The impact of alpha-1 antitrypsin augmentation therapy on neutrophil-driven respiratory disease in deficient individuals. J Inflamm Res. 2018;11:123-34.

10. Rouhani F, Paone G, Smith NK, Krein P, Barnes P, Brantly ML. Lung neutrophil burden correlates with increased pro-inflammatory cytokines and decreased lung function in individuals with alpha(1)-antitrypsin deficiency. Chest. 2000;117:250S-S251.

11. Kalsheker NA. Molecular pathology of alpha 1-antitrypsin deficiency and its significance to clinical medicine. QJM Mon J Assoc Physicians. 1994;87:653-8 (PMID: 7820538).

12. Billingsley GD, Walter MA, Hammond GL, Cox DW. Physical mapping of four serpin genes: alpha 1-antitrypsin, alpha 1-antichymotrypsin, corticosteroid-binding globulin, and protein C inhibitor, within a 280-kb region on chromosome 14q321. Am J Hum Genet. 1993;52:343-53.

13. Matamala N, Martínez MT, Lara B, Pérez L, Vázquez I, Jimenez A, et al. Alternative transcripts of the SERPINA1 gene in alpha-1 antitrypsin deficiency. J Transl Med. 2015:13:211.

14. Kalsheker N, Morley S, Morgan K. Gene regulation of the serine proteinase inhibitors alpha1-antitrypsin and alpha1-antichymotrypsin. Biochem Soc Trans. 2002:30:93-8.

15. Perlino E, Cortese R, Ciliberto $G$. The human alpha 1-antitrypsin gene is transcribed from two different promoters in macrophages and hepatocytes. EMBO J. 1987;6:2767-71.

16. Knoell DL, Ralston DR, Coulter KR, Wewers MD. Alpha 1-antitrypsin and protease complexation is induced by lipopolysaccharide, interleukin-1 $\beta$ , and tumor necrosis factor- $a$ in monocytes. Am J Respir Crit Care Med [Internet]. 1998 [cited 2020 Sep 3];157:246-55. Available from: https://doi. org/10.1164/ajrccm.157.1.9702033

17. Boutten A, Venembre P, Seta N, Hamelin J, Aubier M, Durand G, et al. Oncostatin $\mathrm{M}$ Is a potent stimulator of $a_{1}$-antitrypsin secretion in lung epithelial cells: modulation by transforming growth factor- $\beta$ and interferon- $\gamma$. Am J Respir Cell Mol Biol [Internet]. 1998 [cited 2020 Sep 3];18:511-20. Available from: https://doi.org/10.1165/ajrcmb.18.4.2772

18. Paczek L, Michalska W, Bartlomiejczyk I. Trypsin, elastase, plasmin and MMP-9 activity in the serum during the human ageing process. Age Ageing. 2008;37:318-23.

19. Twina G, Sheiner E, Shahaf G, Yaniv Salem S, Madar T, Baron J, et al. Lower circulation levels and activity of a-1 antitrypsin in pregnant women with severe preeclampsia. J Matern-Fetal Neonatal Med Off J Eur Assoc Perinat Med Fed Asia Ocean Perinat Soc Int Soc Perinat Obstet. 2012:25:2667-70.

20. Baron J, Sheiner E, Abecassis A, Ashkenazi E, Shahaf G, Salem SY, et al. a1-antitrypsin insufficiency is a possible contributor to preterm premature rupture of membranes. J Matern-Fetal Neonatal Med Off J Eur Assoc Perinat Med Fed Asia Ocean Perinat Soc Int Soc Perinat Obstet. 2012;25:934-7.

21. Rotondo JC, Oton-Gonzalez L, Selvatici R, Rizzo P, Pavasini R, Campo GC, et al. SERPINA1 gene promoter is differentially methylated in peripheral blood mononuclear cells of pregnant women. Front Cell Dev Biol. 2020;8:550543

22. Ibanez B, James S, Agewall S, Antunes MJ, Bucciarelli-Ducci C, Bueno $\mathrm{H}$, et al. 2017 ESC Guidelines for the management of acute myocardial infarction in patients presenting with ST-segment elevation. Eur Heart J. 2018:39:119-77.

23. Miller MR, Crapo R, Hankinson J, Brusasco V, Burgos F, Casaburi R, et al. General considerations for lung function testing. Eur Respir J. 2005;26:153-61.

24. Contini C, Rotondo JC, Magagnoli F, Maritati M, Seraceni S, Graziano A, et al. Investigation on silent bacterial infections in specimens from pregnant women affected by spontaneous miscarriage. J Cell Physiol. 2018;234:100-7.

25. Malagutti N, Rotondo JC, Cerritelli L, Melchiorri C, De Mattei M, Selvatici R, et al. High human papillomavirus DNA loads in inflammatory middle ear diseases. Pathogens. 2020;9(3):224. 
26. Qiu W, Baccarelli A, Carey VJ, Boutaoui N, Bacherman H, Klanderman $B$, et al. Variable DNA methylation is associated with chronic obstructive pulmonary disease and lung function. Am J Respir Crit Care Med. 2012;185:373-81.

27. Rotondo JC, Borghi A, Selvatici R, Magri E, Bianchini E, Montinari E, et al. Hypermethylation-induced inactivation of the IRF6 gene as a possible early event in progression of vulvar squamous cell carcinoma associated with Lichen Sclerosus. JAMA Dermatol. 2016;152:928.

28. Rotondo JC, Candian T, Selvatici R, Mazzoni E, Bonaccorsi G, Greco P, et al. Tracing males from different continents by genotyping JC polyomavirus in DNA from semen samples. J Cell Physiol. 2017;232:982-5.

29. Mitchell SM, Ross JP, Drew HR, Ho T, Brown GS, Saunders NFW, et al. A panel of genes methylated with high frequency in colorectal cancer. BMC Cancer. 2014;14:54

30. Rotondo JC, Oton-Gonzalez L, Mazziotta C, Lanzillotti C, laquinta MR, Tognon $\mathrm{M}$, et al. Simultaneous detection and viral DNA load quantification of different Human Papillomavirus types in clinical specimens by the high analytical droplet digital PCR method. Front Microbiol. 2020;19(11):591452.

31. Mazzoni E, Di Stefano M, Fiore JR, Destro F, Manfrini M, Rotondo JC, et al. Serum IgG antibodies from pregnant women reacting to Mimotopes of Simian virus 40 large $T$ antigen, the viral oncoprotein. Front Immunol. 2017;8:411.

32. Tognon M, Tagliapietra A, Magagnoli F, Mazziotta C, Oton-Gonzalez L, Lanzillotti $C$, et al. Investigation on spontaneous abortion and human papillomavirus infection. Vaccines. 2020;8:473.

33. Tognon M, Luppi M, Corallini A, Taronna A, Barozzi P, Rotondo JC, et al. Immunologic evidence of a strong association between non-Hodgkin lymphoma and simian virus 40. Cancer. 2015;121:2618-26.

34. Corazza M, Oton-Gonzalez L, Scuderi V, Rotondo JC, Lanzillotti C, Di Mauro G, et al. Tissue cytokine/chemokine profile in vulvar lichen sclerosus: An observational study on keratinocyte and fibroblast cultures. J Dermatol Sci. 2020;100(3):223-6.

35. Preti M, Rotondo JC, Holzinger D, Micheletti L, Gallio N, McKay-Chopin $\mathrm{S}$, et al. Role of human papillomavirus infection in the etiology of vulvar cancer in Italian women. Infect Agent Cancer. 2020;15:20.

36. Langer D, Ciavaglia CE, Neder JA, Webb KA, O'Donnell DE. Lung hyperinflation in chronic obstructive pulmonary disease: mechanisms, clinical implications and treatment. Expert Rev Respir Med. 2014;8:731-49.

37. Gadgil A, Duncan SR. Role of T-lymphocytes and pro-inflammatory mediators in the pathogenesis of chronic obstructive pulmonary disease. Int J Chron Obstruct Pulmon Dis. 2008;3:531-41.
38. Hodge SJ, Hodge GL, Reynolds PN, Scicchitano R, Holmes M. Increased production of TGF-beta and apoptosis of T lymphocytes isolated from peripheral blood in COPD. Am J Physiol Lung Cell Mol Physiol. 2003;285:L492-499.

39. Tahto E, Jadric R, Pojskic L, Kicic E. Neutrophil-to-lymphocyte Ratio and Its Relation with Markers of Inflammation and Myocardial Necrosis in Patients with Acute Coronary Syndrome. Med Arch Sarajevo Bosnia Herzeg. 2017;71:312-5.

40. Jasper AE, Mclver WJ, Sapey E, Walton GM. Understanding the role of neutrophils in chronic inflammatory airway disease. F1000Research. 2019;8.

41. Zarain-Herzberg A, Rupp H. Transcriptional modulators targeted at fuel metabolism of hypertrophied heart. Am J Cardiol. 1999;83:31 H-37H

42. Ahn JK, Pitluk ZW, Ward DC. The GC box and TATA transcription control elements in the P38 promoter of the minute virus of mice are necessary and sufficient for transactivation by the nonstructural protein NS1. J Virol. 1992;66:3776-83.

43. Beckmeyer-Borowko A, Imboden M, Rezwan FI, Wielscher M, Amaral AFS, Jeong $A$, et al. SERPINA1 methylation and lung function in tobaccosmoke exposed European children and adults: a meta-analysis of ALEC population-based cohorts. Respir Res. 2018;19:156.

44. Zglejc-Waszak K, Waszkiewicz EM, Franczak A. Periconceptional undernutrition affects the levels of DNA methylation in the peri-implantation pig endometrium and in embryos. Theriogenology. 2018;123:185-93.

45. Franczak A, Zglejc-Waszak K, Martyniak M, Waszkiewicz EM, Kotwica G. Peri-conceptional nutritional restriction alters transcriptomic profile in the peri-implantation pig embryos. Anim Reprod Sci. 2018;197:305-16.

46. Barton DE, Francke U. Activation of human alpha 1-antitrypsin genes in rat hepatoma $x$ human fibroblast hybrid cell lines is correlated with demethylation. Somat Cell Mol Genet. 1987;13:635-44.

47. Milger K, Holdt LM, Teupser D, Huber RM, Behr J, Kneidinger N. Identification of a novel SERPINA-1 mutation causing alpha-1 antitrypsin deficiency in a patient with severe bronchiectasis and pulmonary embolism. Int J Chron Obstruct Pulmon Dis. 2015;10:891-7.

\section{Publisher's Note}

Springer Nature remains neutral with regard to jurisdictional claims in published maps and institutional affiliations.
Ready to submit your research? Choose BMC and benefit from:

- fast, convenient online submission

- thorough peer review by experienced researchers in your field

- rapid publication on acceptance

- support for research data, including large and complex data types

- gold Open Access which fosters wider collaboration and increased citations

- maximum visibility for your research: over $100 \mathrm{M}$ website views per year

At BMC, research is always in progress.

Learn more biomedcentral.com/submissions 